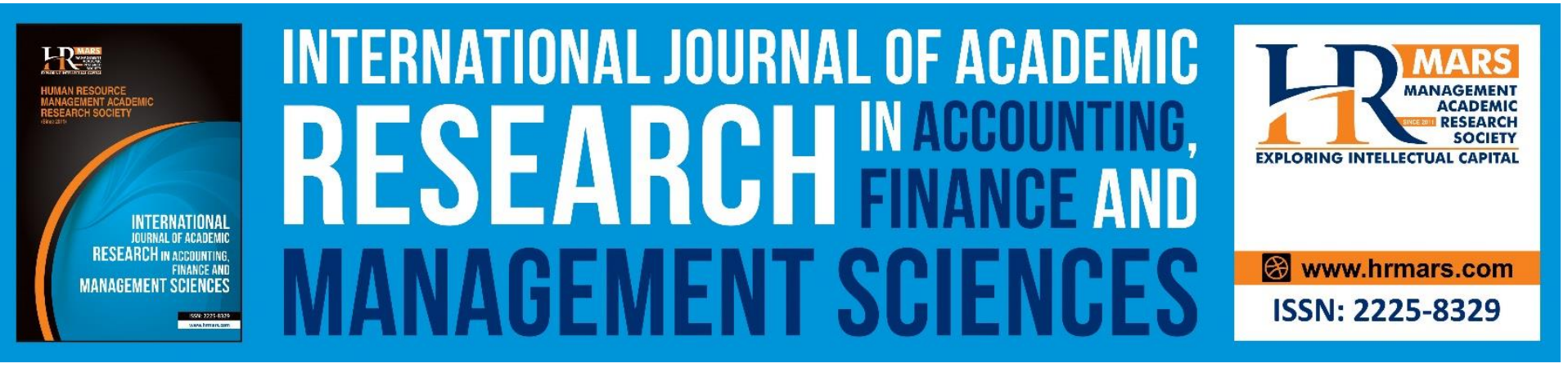

\title{
Determinants of Preferred Export Logistics Gateway in Malaysia Halal Product Industry
}

\author{
Shahrin Nasir, Mohd Hafiz Zulfakar and Abdul Khabir Rahmat
}

To Link this Article: http://dx.doi.org/10.6007/IJARAFMS/v11-i1/9823

DOI:10.6007/IJARAFMS /v11-i1/9823

Received: 06 January 2021, Revised: 03 February 2021, Accepted: 27 February 2021

Published Online: 20 March 2021

In-Text Citation: (Nasir et al., 2021)

To Cite this Article: Nasir, S., Zulfakar, M. H., \& Rahmat, A. K. (2021). Determinants of Preferred Export Logistics Gateway in Malaysia Halal Product Industry. International Journal of Academic Research in Accounting Finance and Management Sciences, 11(1), 489-498.

Copyright: (c) 2021 The Author(s)

Published by Human Resource Management Academic Research Society (www.hrmars.com)

This article is published under the Creative Commons Attribution (CC BY 4.0) license. Anyone may reproduce, distribute, translate and create derivative works of this article (for both commercial and non-commercial purposes), subject to full attribution to the original publication and authors. The full terms of this license may be seen

at: $\underline{\text { http://creativecommons.org/licences/by/4.0/legalcode }}$

Vol. 11, No. 1, 2021, Pg. 489 - 498

http://hrmars.com/index.php/pages/detail/IJARAFMS

JOURNAL HOMEPAGE

Full Terms \& Conditions of access and use can be found at http://hrmars.com/index.php/pages/detail/publication-ethics 


\title{
Determinants of Preferred Export Logistics Gateway in Malaysia Halal Product Industry
}

\author{
Shahrin Nasir, Mohd Hafiz Zulfakar and Abdul Khabir Rahmat
}

Faculty of Business and Management, Universiti Teknologi MARA, Kampus Puncak Alam, Selangor \&

Malaysia Institute of Transport (MITRANS), Universiti Teknologi MARA, Shah Alam, Selangor

Email: shahrin378@uitm.edu.my,mohdhafiz@uitm.edu.my, abdulkhabir@uitm.edu.my

\begin{abstract}
Halal market is becoming increasingly lucrative, and therefore highly competitive. In view of the vast economic potential of the global Halal industry, under Third Industrial Master Plan, (2006-2020), Malaysia has formulated a plan to strategize Halal industries as a new sector that can contribute to its economic growth and position herself as the Global Halal Hub. To further strengthening the industry competitive advantage and catalyst for growth a strategic approach has been further developed in Malaysia Eleventh Plan (2016-2020). However, Malaysia export trend and neighbouring country re-export and transhipment activity indicates that there is a potential for Malaysia halal product manufacturers and its logistics provider to divert their export from local logistics gateway to neighbouring country for shipping their goods to final destination country. This study aims to provide preliminary insight into the determinant factors that influence the manufacturers and logistics provider, specifically the freight forwarder decision for the choice of preferred export logistics gateway and develop a strategy to overcome Malaysia halal product being export through neighbouring country logistics gateway. Therefore, in meeting the aims of this study, a qualitative analysis method has been adopted. Structured and unstructured in-depth interviews were conducted with participants selected from three main category of stakeholders involved in export activity industry. Purposive sampling was use to select the participants. Every category of participants was interviewed using a standard set of interview questionnaires guide. All interviews were properly recorded, coded and analysed using thematic analysis. Outcomes of the interviews were triangulated with the focus group discussion in the validation process. The key findings of this study can be categorized into three determinant factors, namely services, infrastructures and costs
\end{abstract}

Keywords: Halal Product, Gateway.

\section{Introduction}

Since 1974, the Research Center of the Islamic Affairs Division of the Prime Ministers Office has started with the Halal certification However, it was in 1994, the Halal Logo certificate was issues. The halal development in Malaysia has become important and in 2002, JAKIM was established in order to look into all activities in halal certification.tion Malaysia as the Global Halal Hub. To further 
INTERNATIONAL JOURNAL OF ACADEMIC RESEARCH IN ACCOUNTING, FINANCE AND MANAGEMENT SCIENCES

Vol. 11, No. 1, 2021, E-ISSN: 2225-8329 @ 2021 HRMARS

assist the rapid growth of halal food industry, the government formed Halal Development Corporations (HDC) in 2006 with the responsibilities to position Malaysia as the Global Halal Hub industry development in Malaysia. "Furthermore, a Halal hub will create opportunities to penetrate the Halal market on a global scale" (Dali et al., 2007; Borzooei \& Asgari, 2013).

To facilitate the Halal industry in Malaysia, three main agencies are responsible for completing the tasks. The three agencies are, The Ministry of International Trade and industritry (MITI), Jabatan Kemajuann Islam Malaysia (JAKIM) and the department of Standards Malaysia (Standrads Malaysia). Every agency has its role, MITI, under his agenciy HDC, need to developed $d$ a strategic plan in order to fine the right incentives in Halal product and services. MITI also involve with Standard Malaysia in getting Malaysia Halal standard to be recognised at the international level. Aziz et.al, (2014) historical study revealed that JAKIM was established in 1981 as the Islamic Centre with main task to perform existing duty of governing Islamic related affairs. Due to increasing demand for halal market globally, there is a need for improvement in the rules and regulations of all the process and activities within the halal market governance to be more effective and efficient. Thus, this situation has resulted JAKIM's role and authority become more significant and has been expanded as the country's sole certification body that authorizes Halal certificate for local and export markets and execution body for halal standard guidelines procedure until today.

The Department of Standards Malaysia is an agency under the ambit of the Ministry of Science, Technology and Innovation (MOSTI) was officially launched on 28 August 1996 subsequent to the incorporation of Standards and Research of Malaysia (SIRIM) into SIRIM Berhad. STANDARDS MALAYSIA is the national standards and accreditation body of Malaysia governed by Standards of Malaysia Act 1996 (Act 549) in performing its roles and tasks.

\section{Literaure Review}

There are three core components of Halal logistics, namely, direct contact with haram (prohibited), risk of contamination and perception of the Muslim consumer (Tieman, 2011). Direct contact or cross-contamination with Haram products will convert the Halal product status to nonHalal, as a result not allowed to be consumed by Muslims. Haram products are define as flesh of swine, blood, carrion and intoxicants (Kamali, 2010).In order to make sure total Halal logistics implementation (Zulfakar, Anuar, \& Talib, 2014)all Halal products need to be segregated or separated from non-Halal product or substance from the entire supply chain up to the point of final destination for consumption.

Freight forwarders has always been the most critical role in facilitating cross-border trade and global carriage of goods through respective logistics gateway. The Market expansion and active trade development are caused by the increase of goods production in 17th century. This has led to the emergence of freight forwarding services (Burkovskis, 2008). Freight forwarder functions as logistics intermediary between carrier and shipper, and arrange related clearing services or forwarding (Saeed, 2013). Freight forwarder has been recognized as an important link in logistics intermediaries for their experiences in coordinating cross border trade, therefore many companies has started to use freight forwarder for carriage of their goods internationally (Murphy \& Daley, 2001). Murphy et.al, (1992) also described freight forwarder as an international trade expert who can provide multitasking coordination activity to support the shipment delivery worldwide. With this information, choosing the right logistics gateway for the Malaysia shipper can used. 
INTERNATIONAL JOURNAL OF ACADEMIC RESEARCH IN ACCOUNTING, FINANCE AND MANAGEMENT SCIENCES

Vol. 11, No. 1, 2021, E-ISSN: 2225-8329 @ 2021 HRMARS

Freight forwarders function as an important coordination centre within the supply chain of shipper/consignees, shipping lines and ports. For instance, freight forwarders assist shippers to identify and arrange suitable transport company, consulting rates, manage transport agreement and supervise the contracts implementation. From carriers' point of view, freight forwarder acting as a party who contribute to the shipment space fulfilment by consolidating various shippers' goods. Shipping liners need only to work with one freight forwarder instead to deal with all the shipment owners (Manic, 2013). Freight forwarder also play an important role in coordinating a shipment of numerous freights without compromising any delays and ensure quality delivery. Furthermore, freight forwarder able to negotiate a discount rate for freight and insurance by arranging high volume of shipment to carrier companies

\section{Methodology}

The qualitative approach has been chosen for the study. This method was adopted because it would help the researchers to obtain in-depth result for the study. Qualitative research is conducted in the situation where communication in person with the respondence is vital. (Schensul et al (2013). It would be able to focus on the meanings which imparted by the respondents. This would include the behavioral and facial expression during the process. The approach would consider the social, cultural belief and physical contact which the respondents participate in. . In detail, there are numerous types of qualitative research and one of the types is case study. According to Yin (2011), he defined that case study is a study a phenomenon in its real world. Additionally, case study has several case studies designs. The general characteristics of research designs serve as a background for considering the specific designs for case studies. Thus, this study applicable single case study where is an appropriate design under several circumstances (Yin, 2001).

The instruments fo data collection is interview. Detailed information can be obtained from the process (Creswell, 2013). Samples were obtained from Federation of Malaysian Freight Forwarders lists or other available and reliable sources such as Matrade, Jabatan Kastam Diraja Malaysia, Selangor Freight Forwarders Association and industry networking. The freight forwarder provider was selected due to they are the party who presence on premises of all the logistics hub gateway for the export and import related activities. Secondly, they have the best knowledge of the logistics gateway operation activities, services and facilities in order to consult, advice and influence the potential halal product export manufacturer for the choice of the logistics gateway decision. Study by (Kupfer et.al, 2011) identify that forwarders presence on the airport terminal turned out to be the most important factors for the logistics gateway terminal choice decision.

The study on site provides information by talking directly to participants and observing their behavior and action within their context is a major characteristic of qualitative research. By doing interview, more detailed information can be obtained when the participants giving their feedback to a given questions in interview guide 
INTERNATIONAL JOURNAL OF ACADEMIC RESEARCH IN ACCOUNTING, FINANCE AND MANAGEMENT SCIENCES

Vol. 11, No. 1, 2021, E-ISSN: 2225-8329 @ 2021 HRMARS

The respondents for the study were as follows:

\begin{tabular}{|l|l|l|l|}
\hline & Sector & Type & Working experience \\
\hline a) & Port Operator: 2 respondents & $\begin{array}{l}\text { Respondent A } \\
\text { Respondent B }\end{array}$ & $\begin{array}{l}10 \text { years } \\
13 \text { years }\end{array}$ \\
\hline b) & Shipping Lines : 1 respondent & Respondent C & 7 years \\
\hline c) & $\begin{array}{l}\text { Halal Product Manufacturer: 1 } \\
\text { respondent }\end{array}$ & Respondent D & 9 years \\
\hline d) & Freight Forwarders: 3 respondents & $\begin{array}{l}\text { Respondent E } \\
\text { Respondent F } \\
\text { Respondent G }\end{array}$ & $\begin{array}{l}5 \text { years } \\
15 \text { years } \\
9 \text { years }\end{array}$ \\
\hline
\end{tabular}

\section{Findings and Discussion}

The interview questions were constructed and adopted from previous study to gain insight into the findings. From that, the researcher developed clear and precise questions in an attempt to capture the nature of information from the respondents. The findings from the analysis are organized into three broad theme which are Service Performance, Overall Charges Cost, and Infrastructure Development. These three themes which is the component of factor that influencing potential export trade diversion in Malaysia halal product industry.

\section{Service Performance}

Service performance by Malaysian ports has been at par with other logistics gateway such as Singapore. The service provided by the ports are standardize, however the if we compare in terms of facilities, Port Klang might have a slight disadvantage, since most of the facilities are old. From the interview research, there is no much difference between ports. The services that are provide by other ports. For example, Cargo Services, Container Services, Ferry Services, Security Services, Fire \& Rescue Services, Marine Services and Swettenham Pier Cruise Terminal.

"Actually, in terms of ports, if we do not go to the place, we do not know how the facility is like. Normally it will be much less. Hard to answer. In terms of better facilities, better service, it is difficult to make a comparison. Normally it just a standard port. For example, I once went to China's port which at Dalian Port China. Compared to their port with our port, Maybe due to their old port. Their old facilities, old warehouse, old style. That's the difference. If in Port Klang, there is a difference between North Port and Westport. Because of Westport is new. All of their facilities are the latest. South port and North port are an old port." Respondent $A$

Some manufacturers has a few branches all over Malaysia. Therefore, due to the location, they chose Port Klang as their frequent port to do their export services to worldwide. Besides that, based on the experience, the respondent also had stated the comparison between Malaysia main ports and Dalian port China. Roughly compared, main ports in Malaysia provide better services compared to Dalian port in China. Dalian port is an old port. Thus, the facilities they provide is old for example their warehouse. A few respondents stated that the service performance are depending on the superiority 
INTERNATIONAL JOURNAL OF ACADEMIC RESEARCH IN ACCOUNTING, FINANCE AND

MANAGEMENT SCIENCES

Vol. 11, No. 1, 2021, E-ISSN: 2225-8329 @ 2021 HRMARS

of the port itself. However, the differences are for the sailing frequiecies of the shipping line $s$ for the respected ports.

Where sometimes Port Klang gives better service compared to Singapore. And sometimes Singapore gives better services compared to Port Klang. Singapore ports might be superior in providing a better service compared to Malaysia. For instance, in terms of their productivity and flexibility in Port Tariff where Singapore is much positive. Besides, another issue is congestion at Malaysia port. This will affect liners planning that can lead to delayed and omitted.

"This is subjective. In term of sailing frequencies, yes Singapore is having more Mainline vessels, but again our premier ports for example Port Klang and Tanjung Pelepas are also can match up to the frequencies level. As well as top 5 shipping lines are already servicing our ports for example Maersk, MSC, CMA CGM, Evergreen and Hapag Lloyd. And few of them have shifted operations to Malaysian ports on specific services/routes." Respondent $C$

The respondents also mentioned that Singapore ports provide a better service compared to Malaysia. For example, in terms of their productivity and flexibility in Port Tariff where Singapore is much positive. Besides, another issue is congestion at Malaysia port. This will affect liners planning that can lead to delayed and omitted.

"Malaysia port at current have less calling for Mother vessels in which liners tend to priorities SGSIN as main hub. The overall productivity is much lesser compared to Singapore port. The flexibility on Port tariff is where Singapore is much positive. Congestion at Malaysia port also affected liners planning for post of call especially when vessel is being delayed and omitted. Such scenario is being handled by Singapore much better and their counter measures are much faster." Respondent $F$

\section{COST}

Cost is one of the important factors for any company to choose any ports as the gateway. Cheaper cost to the port customers is always been the attraction in the logistics business. By comparing between Malaysia and Singapore ports, there were at times where Malaysia ports offers more competitive rates to their customer. Usually, the customer is given the quotation for any type of services required by them. The freight forwarders follow the chargers given to them and some of the charges are fixed.

Usually, the port has adjusted some cost. We have to follow. Customs already set how much the charges as we make clearance a document. If 10 years ago, DGC (Depot Gate Charges) costs only RM5. Now it costs RM35. All the charges are decided by customs not us. That means, if the shipper from oversea, for example, Thailand, arrived here we make a clearance, freight forwarding make clearance we will follow that charges." Respondent $G$

"Our customer who imports the cargo, we handle for them to make all the clearance. We have already told him about the detail of the charges and the quotation. That's why I say, sometimes when we give that quotation, customers say it was expensive. Others can give cheap charges, then they take 
INTERNATIONAL JOURNAL OF ACADEMIC RESEARCH IN ACCOUNTING, FINANCE AND MANAGEMENT SCIENCES

Vol. 11, No. 1, 2021, E-ISSN: 2225-8329 @ 2021 HRMARS

someone else. They did not differentiate the customs charge. Customs charges are all the same. Maybe from overseas, from the origin port. For example, Dahlia Port China to Port Klang, we say 600USD. But that time rate may be in 650USD. We charge more than 50USD." Respondent F

The respondents stated that the freight forwarders will choose the alternative port according to location factor. For example, if the shipper is at the southern region (Pontian/Kulai - Pasir Gudang), they will have Singapore Ports as an alternative's ports. However, with the currencies between ringgit and SGD, Singapore is much more costly compared to ringgit Malaysia. Therefore, 3PL will reconsider to choose local ports instead.

The costing or charges are not the first priority. Some manufacturers mighthave specific criteria for their product such as halal product. Therefore, the supply chain process will stick with halal criteria that has been stated in their freight forwarders that including with port as well. Besides, Singapore ports although they serve better services compared to Malaysia but they do not have the halal certificate, thus they will still remain with local ports. Even though the port they divert to charge them high, they will still stay because of they want Halal service.

"When we talk about logistics, it covers everything including safety, hygiene, quality workers, documentation. Of course, for cost but that's not the main. To choose which port for our alliance or to work together, we will look at the criteria that we have already set in our freight forwaders. What we want what they provide is the same or not. To assist in halal integrity. Respondent $D$

"In port, we look logistics is more to maximize profit. When we talk about this, to give them an additional cost and not many customers want to. We have to remember if we use halal logistics, the charge is premium. The charge is more expensive. It means that the port itself if they want to use a halal logistic, the charges are high. Anyhow, customers who provide halal logistics will find it. For example, we have MMC to FFGC to who make halal products, they will make it too." Respondent $D$

Singapore is well known for its strategic locations and their frequency of calls is high. This gives benefit to the company itself where they can get a better rate when making an export service. For example, based on the respondent experience, he once gets a free export from Port Klang to Hong Kong. This is because there's a shipment from there needs to use their boxes. So, the respondent negotiates with the port agent and got it without being charge. Thus, the frequency of calls is important where it can create a competition and gives benefit to 3PL which is lower charges.

"If I want to send one container 40ft from my factory to the USA for example. Via Port Klang: this is an assumption not accurate. One container costs to USA via Port Klang is 2000USD but Via Singapore port is cots 1800USD. The difference is 200USD, which approximately RM800 per container. If I have to send 20 containers a month, Singapore Ports would be a better choice. That is the one of the reasons but not only the case because sometimes Port Klang also is much cheaper than Singapore Ports." Respondent E 
INTERNATIONAL JOURNAL OF ACADEMIC RESEARCH IN ACCOUNTING, FINANCE AND MANAGEMENT SCIENCES

Vol. 11, No. 1, 2021, E-ISSN: 2225-8329 @ 2021 HRMARS

The respondent stated that the charges are depending on the service itself. Most of their customer is concern about the costing and budget. It is also depending on the location as well. If the logistic companies are from Northern region (Perlis, Kedah, Penang); they will choose Penang port instead to make an export service to neighbors' country (China, Philippines, India). This is because they consider about the transportation cost. The longer the journey is, the higher the cost will be.

\section{Infrastructure Development}

The port infrastructure in Malaysia has improved over the recent years. It is difficult to conduct comparison for the ports. However, based on the respondent experience, he stated that local port is better compared to some ports in the region. Moreover, West Port serve better facilities because West Port is a new port compared to other ports in Port Klang. Westport Malaysia is a leading port in the world supported by superior productivity and water depth of 15-17.5 meter. This makes us the preferred hub port for the shipping lines in this region.

Three main infrastructure development which would assists customers to do business at Port Klang. Firstly, investing on the one stop center. This center is to facilitate efficient trade at ports. The main functions of this center include consolidating and introducing the best practices for the logistic industry. Other that, this center also facilitates the establishment of port related business in Port Klang and organize dialogues with port users. Secondly is Port Klang as a distribution hub. In order to maximize the profit margin, Port Klang need for an efficient distribution park or Distripark as Malaysian economy rapidly growing and demanding a smoother flow of goods into or out of the country. Distribution Park is built on each port except for Southport. For Northport Distribution Park it is handled by Northport Distripark Sdn. Bhd and likewise for Westport, it is handled by Westport Distripark Sdn. Bhd. Both disrtriparks offers adequate and sophisticated facilities to their client.

"Malaysia Premier ports for example Westport/Northport/Tanjung Pelepas have started in investing in "one stop center" and "distribution hubs" and emulating Singapore free port concept in order to compete and ensure the infrastructure keep up if not better than Singapore. We can see Free Zone area, Distripark and Manufacturing hubs being operated near/within the port areas. Beside there are some incentive and fast track custom/documentation processes in place to ensure better productivity" Respondent $A$

Moreover, the Free port concept for Malaysia ports has given a great advantage for the ports. Port Klang was declared as a free commercial zone by the minister of finance. In this zone only commercial activity are allowed and any manufacturing activity is banned. The activities allowed in the free zone are transshipment, consolidation of cargo for subsequent shipment, regional distribution, trading activities, storage or deferment of duty on import cargo, inspection and sampling, and value-adding such as break-bulking, labeling and etc. One of advantages of using free zone is being duty-free and exemption on sales tax. Free commercial zone also gives greater flexibility compare to normal zone. It insures goods for just their value and ocean freight. 
Another infrastructure that needs to be further improved in Port Klang, is the last mile delivery infrastructure. The roads to Port Klang is very much congested. This has created a massive traffic congestion which would affects the delivery to Port Klang. The current road to/from ports and the infrastructure inside the ports need to be improved. Malaysia is also well known with the traffic. But that is not always the case. This is because, they operate their servicer usually not during the peak hours. Therefore, they can avoid the traffic congest. Furthermore, every step and move made by their freight forwarders will be detect using the GPS system. The location accuracy is anywhere from 100 to 10 meters for most equipment. By this device, company can ensure that the Estimated Time Arrival (ETA), Estimated Time Departure (ETD) and the journey secure towards the destination.

Singapore has officially decided to consolidate all its container port activities at Tuas over the long term with the first berths to be built there in 10 years. This will be spent on leading infrastructure and the latest port technology, such as an automated container yard and unmanned cranes. Tuas is suitable given its "sheltered deep waters and proximity to major industrial areas and international shipping routes. The target is for Tuas Port to handle up to 65 million TEUs a year, nearly double the current total container handling capacity of 35 million TEUs. It will also result in greater efficiency. This means that the city terminals at Tanjong Pagar, Keppel and Brani, plus those at Pasir Panjang will eventually be merged at Tuas. As from this, Malaysia should be concern about it as it can create a competitive and will become more challenging for Malaysia ports.

\section{Conclusions}

It can be concluded that the three components of factors influencing potential export logistics gateway diversion in Malaysia halal product industry which are service performance; overall charges and infrastructure development is well discussed by the companies.

Lastly is to take Singapore port as benchmark for Malaysia. Singapore port is one of the wellknown ports in the world. Recently, the development in their Tuas port brings more challenge for Malaysia. Therefore, Malaysia needs to take this challenge in order to compete to be one of the best choices for logistics gateway. Malaysia and Singapore is a neighborhood country. Thus, if it possible for Singapore to be a well-known port, so does Malaysia.

In a conclusion, in order to achieve, there must be help from the government as well. For example, by giving subsidies and incentives to the freight forwarder which plan for the cargo movement. This is because to have change can cause a higher cost. Moreover, government also need to make investment in terms of the development of the ports itself for a better service and facilities

\section{References}

Borzooei, M., \& Asgari, M. (2013). Establishing a Global Halal Hub: In-Depth Interviews. International Journal of Academic Research in Business and Social Sciences, 3(10), 169-181.

Raof, N. A., Aziz, N. A., Ramli, N. (2014). JAKIM : Governors of Halal Affairs. PROCEEDING PAPER International Halal Conference (INHAC 2014), Istanbul, Turkey. 
INTERNATIONAL JOURNAL OF ACADEMIC RESEARCH IN ACCOUNTING, FINANCE AND

MANAGEMENT SCIENCES

Vol. 11, No. 1, 2021, E-ISSN: 2225-8329 @ 2021 HRMARS

Tieman, M. (2011), "The Application Of Halal In Supply Chain Management: In-Depth Interviews", Journal Of Islamic Marketing, Vol. 2 No. 2, Pp. 186-195

Kamali, M. H. (2010), "The Halal industry from the Shariah perspective", Islam and Civilisational Renewal, Vol. 1 No. 4, pp. 595-612.

Zulfakar, M. H., Anuar, M. M., \& Ab Talib, M. S. (2014). Conceptual framework on Halal food supply chain integrity enhancement. Procedia-Social and Behavioral Sciences, 121, 58-67.

Burkovskis, R. (2008). Efficiency of freight forwarder's participation in the process of transportation. Transport, 23(3), 208-213.

Saeed, N. (2013). Cooperation among freight forwarders: Mode choice and intermodal freight transport. Research in Transportation Economics, 42(1), 77-86.

Murphy, P. R., \& Daley, J. M. (2001). Profiling international freight forwarders: an update. International Journal of Physical Distribution \& Logistics Management, 31(3), 152-168.

Murphy, P. R., Daley, J. M., \& Dalenberg, D. R. (1992). Profiling international freight forwarders: a benchmark. International Journal of Physical Distribution \& Logistics Management, 22(1), 3541.

Manic, B. (2013). Benchmarking Analysis of Port Services from a Perspective of Freight Forwarders (Doctoral dissertation, TU Delft, Delft University of Technology).

Yin, R. K. (2011). Qualitative Research From Start To Finish. The Guilford Press.

Kupfer, F., Goos, P., Kessels, R., Van De Voorde, E., \& Verhetsel, A. (2011). The Airport Choices In The Air Cargo Sector: A Discrete Choice Analysis Of Freighter Operations. In European Transport Conference

Creswell, J. W. (2013) Research Design_Qualitative, Quantitative, And Mixed Methods ApproachesSage Publications, Inc. 